\title{
The Role of Social Workers in Empowering Socioeconomic Women in the Time of Covid-19 Pandemic
}

\author{
Rezka Arina Rahma ${ }^{1, *}$ Sucipto $^{2,}$ Monica Widyaswari ${ }^{3}$ \\ 1,2,3 Department of Non-Formal Education, Universitas Negeri Malang \\ *Corresponding author. Email: rezka.rahma.fip@um.ac.id
}

\begin{abstract}
Covid-19 pandemic had changed all the social life and economic. Empowerment is one of the efforts to strengthen the ability and skill, which refers to the condition or results attained by a social change, through the enhancement of physical, mental, social, and economic ability to fulfill the basic needs. This research aims to identify Social Workers (SW) in empowering socioeconomically versatile women. This research used a descriptive qualitative approach, and the subjects of the research are social workers and clients of economically versatile women in Putat Jaya Urban Village, Surabaya. The location of the research is Putat Jaya Urban Village Sawahan District Surabaya City in which it was used to be the biggest Red-Light District in Southeast Asia, the Dolly Red-Light District. Data collection methods used were interviews, observation, and literary research. These research results are social workers as (1) facilitators; (2) motivators; and (3) companions. Empowerment conducted by SW resulted in the ability to do something useful and had never been done before, improving the power and existence, the feeling of more secure and comfortable by the client, and problem-solving alternatives. Meanwhile, the impact of the role of SW is the ability to work independently, the ability to run their businesses by using their skills; having the high motivation to improve their talents and sparing their time to express their hobbies; having easy access to public service, especially the programs held by the government.
\end{abstract}

Keywords: Social Workers, Empowerment, Socioeconomic Women

\section{INTRODUCTION}

Based on the data from Statistics Indonesia (BPS), Survey on National Socioeconomics (Susenas) in 2009, poor people, socioeconomically versatile women 2,500,000 people. Neglected children, neglected babies, neglected older people 7,191,551 people, remote local communities of 213,080 households, disability and immoral behavior, beggars, homeless people, exprisoners, People living with HIV-AIDS, victims of drug abuse, 3,872,287 people, natural and social disasters casualties 1,461,744 households, exploitation and discrimination of the victims of the violence, migrant workers with social problems 889,987 people.

Based on the data Department of Social Affairs in 2008 , the number of economically versatile women in East Java is 191,669. According to the Social Office of Surabaya, the number of economically versatile women in all districts in Surabaya is 3,895 people. In Putat Jaya Urban Village in Surabaya, there are 18 economically versatile women, and the low-income families are of 249 households.

The number of economically versatile women in Putat Jaya Urban Village are of many backgrounds, such as ex whores of Dolly red zone district, women with no income, widows, and Menur Asylum patients Surabaya. It is expected that social workers will help them get better lives and recover their social and economic condition.

The problems of women who are economically vulnerable need to be a common concern. The welfare of women is essential because that reflects the family's welfare and can guarantee the welfare of other groups. Furthermore, many global initiatives have documented women's empowerment as a priority for action. The main objectives of development should be to empower women to strengthen their capacities [1].

In order to decrease the number of economically versatile women, the social workers in Putat Jaya Urban 
Village, Sawahan District empowering social welfare problems (PWSWP) by giving job opportunities for productive people, training them, et cetera. The empowerment had decreased the number of economically versatile women up to $39.9 \%$ in seven years since social workers in Putat Jaya Urban Village, Sawahan District. This research was urgent in order to avoid discrimination and stigma from the community.

Harini dan Listyaningsih in Fajarwati et al. stated that the economically vulnerable women are women who are considered responsible for their household are (1) women are not married and are responsible for their household; (2) woman is married but has a separate residence from her husband so that the woman is head of the household, and; (3) women are divorced or divorced and have not remarried and have not returned to the family. In general, adult women are not married or widowed and do not have enough income to meet their basic daily needs [2].

Based on the Decree of the Minister of Social Affairs Number. 24/HUK/1996, the criteria of the economically versatile women are : (a) Women of 18-59 years of age; (b) They have low income and cannot fulfill minimum physical needs (based on the poor people category); (c) They have low education level (not graduated/graduated from elementary school); (d) Wives left by the husbands and cannot work; (e) Being sick and cannot go to work.

In Irma's opinion, women are stereotyped as weak and useless by society. It happens because the culture still had a patriarchal view, and women are sometimes inhibited to improve themselves. Empowerment will improve women with the knowledge and skills they can get. Besides, their knowledge and skills will enable them to face the problems in their lives [3].

Poverty does not only relate to the economic aspect but also other aspects. Poverty may also be caused by the weakness of moral, social, and cultural aspects. Besides, it is also caused by the uneven distribution of wealth resulting from the development. The logic is that poor people get low and uncertain incomes. The low income is caused by the low skill of the Human Resources (HR), the lack of capital, and the entrepreneurship's lack of networking.

In order to improve the quality of HR through education, we need to create socio-culture engineering for the students. Therefore, the national education system should try to create a learning process that can optimize the learners' talent and skill, and in turn, it will bring the advancement of the country. There are many phenomena in this life regarding social, culture, economics, and politics that give us a clear image that everything will be useless if we cannot utilize what we have. It is rooted in the low quality of HR. This problem will be solved if HR can show work productivity. HR should also show that they have the knowledge, skills, and proficiency they had gained from their education. Knowledge is power, and the lack of knowledge is poverty and misery. Therefore, the main factor in emancipated women from poverty is knowledge. The critical aspects of the empowerment process are education and capacity making. Educated women perform an essential role in family decision making. Education to build skills and abilities that an individual needs to feel competent is critical for enhancing psychological empowerment. Education increase women's financial independence; therefore, they are regarded as powerful means of empowerment [4].

According to the Department of Social Affairs of the Republic of Indonesia (Sriwahyuni in Irma), women empowerment is an effort conducted by the government, local institution, and society to improve the social welfare of women through the improvement of physical, mental, social, and economical empowerment of women in fulfilling the basic needs. From that statement, we can learn that one of the empowerment program's objectives is to solve the versatile economic condition and not negatively impact their lives [3].

There is a bidirectional relationship between economic development and women's empowerment, defined as improving women's ability to access the constituents of development-in particular health, education, earning opportunities, rights, and political participation. In one direction, development alone can play a significant role in driving down inequality between men and women. Also, women's empowerment can, in other words, accelerate development [5].

Covid-19 pandemic had changed all the social life and economic. Empowerment is one of the efforts to strengthen the ability and skill, which refers to the condition or results attained by a social change, through the enhancement of physical, mental, social, and economic ability to fulfill the basic needs.

In Putat Jaya Urban Village, Sawahan District, there are issues of citizens who still cannot fulfill their needs. Especially people with PWSWP, and one of them is economically versatile women. Social welfare problems have snowballed, both in terms of numbers and kinds, caused by an economic crisis, social conflict, natural disaster, and social disintegration. Uniquely there is an independent social worker named Mrs. Puji who lives in this village. She focuses on alleviating the poor in her region. PWSWP empowerment for poor people with various backgrounds of age, occupation, and social status requires patience and a high concentration level.

Dubois and Miley in Wijayanti stated that there are 4 (four) roles of a social worker: (a) improving the capabilities of people to solve the problems, and (b) exploring and connecting resources around the client. Some tasks that a social worker should do in this role 
are: (1) assisting the client in reaching the necessary sources; (2) developing a social service program to be maximally used by the client; (3) improving communication among the social workers in order to solve any problem in giving social services to the client; (4) improving the social service network; (5) promoting social justice through social policymaking [6].

Suharto stated that there are five roles of social workers in social facilitation, which include: (1) Facilitator; (2) Broker; (3) Mediator; (4) Advocate; (5) Protector. According to the Directorate General of Social Empowerment of Welfare Education and Research Agency Department of Social Affairs of Republic of Indonesia (in Wulandari 2011:20), in implementing the function, tasks, and activities of the Social Workers may play roles such as (1) planner; (2) consultant; (3) informant; (4) motivator; (5) facilitator; (6) evaluator [7].

According to Anwas, facilitation is a timeconsuming process, and it needs real and continual action. The empowerment agent needs this facilitation to be better as a facilitator, communicator, motivator, and social consultant [8]. Suharto argued that social facilitation is a strategy that will determine the success of the empowerment program. According to the principle of social work, "to assist people to empower themselves", people empowerment pays attention to strong public participation. Developing and empowering people may involve the social process and action. People in an individual community organize themselves to make plans and collective actions to solve social problems and meet the social needs based on the capability and resources [7].

Kartasasmita in Setyaningsih stated that, in principle, community empowerment is an effort to elevate the pride and dignity of people who live in poverty [9]. Suharto stated that empowerment refers to the capability of people, extraordinarily versatile and weak groups so that they have capabilities in (a) Fulfilling their basic needs so that they have freedom; (b) Reaching out productive resources so that they can increase their incomes and get necessary products and services; (c) Participating in the development process and decisions that have impacts on them [7].

Based on the description above, this research was aimed at identifying the roles of social workers in empowering the economically versatile women, the results of the empowerment of the economically versatile women conducted by the social workers, and the impact of the social workers on the empowerment of the economically versatile women in Putat Jaya Urban Village Sawahan District Surabaya City.

\section{METHODS}

The research approach used is descriptive qualitative, meaning that descriptive qualitative emphasizes human behavior with conditions that are what they are, prioritizing the perspectives of informants, and the process when searching for data sources to obtain in-depth and meaningful information [10].

The researcher paid attention to the field phenomena, interpreted it, and matched it with the objective of the research's objective: describing the roles of social workers in empowering the economically versatile women in Putat Jaya Urban Village, Sawahan Sub District Surabaya City. The primary data sources of this research are one informant and 14 economically versatile women. Lofland in Moleong stated that the primary sources of data in the qualitative research are words and actions; besides, additional data such as documents, etc. Data types are categorized into words and actions, written documents, photos, and statistics [11].

Data collection techniques used in this research are:

a) In-depth Interview

The in-depth interview method is used to gather data or information about social workers, the economically versatile women, people in the community, and the public figures in Putat Jaya Urban Village. The objective of the data collection, in this case, is to get the following information: (a) About the roles of social workers to make better welfare for the economically versatile women; (b) About the impacts of empowerment of the economically versatile women done by the social workers; (c) About the impacts of the roles of the social workers to the empowerment of the economically versatile women in Putat Jaya Urban Village Sawahan District.

b) Participatory Observation

In this research, the researcher used direct observation to observe directly by using an observation guide on the subject phenomena. The subjects are economically versatile women and social workers. The objectives: (a) Collecting data about the activities of social workers in their facilitation in the community; (b) Collecting data about the results of the empowerment of the economically versatile women by the social workers; (c) The impacts of the role of social workers to the empowerment of the economically versatile women in Putat Jaya Urban Village Sawahan District.

\section{c) Documentation}

Data that can be collected from documentation in this research include (a) the profile of the social workers, biodata of the economically versatile women in the empowerment program; (b) the organizational structure of the social workers in putat jaya urban 
village; (c) certificate of merit or award got by the social workers; (c) empowerment process and supporting data.

Instruments of the data gathering are: (a) interview guide; (b) observation guide; (c) self-report or fieldnote; (d) imaging or video recording instruments. Meanwhile, the data analysis techniques are (1) data reduction: summarizing the contacts; category codification; making notes; data filtering, (2) data display; (3) data verification and inferring a tentative conclusion, and it may change in the future if there are other supporting evidence. Because valid and consistent evidence had supported this initial conclusion, we can say that that is a credible conclusion. The result of the verification is a comprehensive and accurate conclusion.

\section{RESULTS AND DISCUSSION}

Data analysis is a step that a researcher should after collecting the field data. After that, field data are written and described in the data presented. The next step is analyzing the filed data based on the theory. Here is the explanation of data analysis from the results of data presentation:

\subsection{The Role of Social Workers in the Empowerment of Economically Versatile Women in Putat Jaya Urban Village, Sawahan District Surabaya City}

The role of social workers in Putat Jaya Urban Village, Sawahan District, Surabaya City is carried out in the form of social services to empower clients' lives (community) economically. In carrying out this mission, the social workers shall have the persistence to overcome any hardship. Social work value includes orientation, thought, and a clear picture in each assumed situation that possibly exists in society and deliver the appropriate solution to meet human needs. Hence, social work should not neglect social work value because it is the key to providing adequate services [12].

As Dubois and Miley stated in Wijayanti, social workers are acquiring a central role in the social service system. As a humanitarian occupation, social workers possess a body of knowledge, body of skills, and values obtained through formal education and professional experience [6]. These three tools shape the approach used in facilitating their clients. In summary, there are four roles of the social worker profession, namely:

a) They were improving the capacity of the community in coping with their problems. In carrying out this role, the social worker identifies the client's constraints in managing their worldly tasks. The social workers also explore the clients' strengths to develop and plan solutions.

b) Exploring and taking advantage of available resources around the client. The tasks of social workers related to this role include: (1) helping clients bring together the resources they need; (2) developing social service programs that will provide optimal benefits for clients; (3) expanding communication among humanitarian workers; (4) overcoming obstacles in the social service process.

c) It is improving social service networks. This role's primary purpose is to ensure that the social welfare system runs compassionately, is sensitive to residents' needs, and is useful in providing social services to the community.

d) Promote social justice through the outlining of social policies. Within the framework of this role, social workers identify social issues and their implications to society life. Based on the findings, the social workers prepare a policy paper that contains recommendations for the drafting of new policies and the improvement or replacement of old policies that are ineffective. Social workers also translate public policies into social programs and services needed by clients under this role.

With social workers' social services, economically versatile women gain a strong passion for prospering their life.

Roles of social workers in the community services provided to economically versatile women in Putat Jaya Urban Village, Sawahan District, Surabaya City are including:

a) Social workers as a facilitator

In empowering their clients or economically versatile women, the social workers have a role in (1) providing access to public facilities and social services; (2) offering goods and services in the form of training or other activities as needed by the client; (3) helping clients of productive age to find a decent work; (4) in the social sector, providing direct assistance in the form of capital funds or loans.

This role is in line with Barker, who argued that the facilitator is responsible for supporting its clients to handle situational or transitional pressures [7]. The services provided by the social workers also following the Directive of Directorate General of Social Empowerment of the Welfare Education and Research Center, Ministry of Social Welfare of Indonesia in Wulandari that stated that social workers are working to provide facilities in the form of goods, equipment, and policies to improve community capacity to carry out various social, economic and institutional activities, and to overcome existing obstacles and problems. The facilitator is the person in charge of supporting the client to handle situational or transitional pressure [13].

Thus it can be concluded that the results are following the statement of Barker in Suharto and Directorate General of Social Empowerment of the Welfare Education and Research Center, Ministry of Social Welfare of Indonesia in Wulandari that mentioned the role of social workers is to support the 
community in handling situational and transitional pressure. Also, provide facilities that will facilitate economic, social, and institutional activities and provide goods and services for economically versatile women according to their needs [7] [13]. This is following the purpose of empowering the economically versatile women are: (a) increasing the role in realizing family welfare, especially the ability to overcome problems and the ability to meet basic needs (physical, psychological and social); (b) increased ability in carrying out the role of wife or as head of the family and as members of the community, so that their social functions can run optimally; (c) increased socio-economic resilience in counteracting the negative impact of the flow of information and preventing and overcoming the occurrence of social welfare problems that are faced independently so that those concerned can carry out the function of prevention and the emergence of poverty [14].

b) Social workers as a motivator

As a motivator, SW delivers the motivational discourse using a door to door method or home visits to each client by telling stories of successful people and providing support to clients who have problems. While helping the clients recognize problems, SW asked about the clients' conditions and problems being faced. SW asked questions directly to the individuals and looked for information from the client's friends or close relatives. There are also community members who come directly to SW for consultation. These methods are different from Sumodiningrat in Anwas, who suggested the transfer of motivation, especially to low-income families, should be made by establishing groups that will simplify organizational arrangement and accelerate community development activities. Afterward, social workers could motivate the community to be involved in empowerment activities, which will increase their income by using their existing capacity and resources [8].

The point is that some actions are carried out following the theory, while others are different because in each case and problem identification, the findings and analysis of problems are diverse. During the interview, the clients revealed the problems they were experienced and the support they needed at the time. On the other hand, the Directorate General of Social Empowerment of the Welfare Education and Research Center, Ministry of Social Welfare of Indonesia in Wulandari, said that social workers should provide stimulation and encouragement to community members, so they can recognize the problems and strength they have. Social assistance should bring in participation expected to change attitudes and mindsets and develop community potential through empowerment activities being made [13].
The two opinions Sumodiningrat in Anwas and Ministry of Social Welfare have similarity in terms both are striving to explore clients' capacity to be developed. The differences in opinions mentioned above occurred due to the problems or cases being encountered; thus, the theory might be different from the actual practice according to the need. However, this study found that SW's motivation is made in the form of providing stimulus or encouragement, verbal and moral support suitable for the client case.

\section{c) Social workers as assistant}

In terms of social workers as an assistant, SW plays a distributor or information channel from the community to government officials. It also plays a role as a mother of children (the economically versatile women) who teach her children to continuously increase their mindfulness that they have potential that can be developed, manage and organize their lives, and find partner institutions that will facilitate empowerment activities.

As conveyed by Sumodiningrat, five critical activities can be carried out in carrying out social assistance [8], namely :

1) Providing motivation

Community, especially the underprivileged families, should be motivated to form groups to simplify organizational and community development activities. They then need to be encouraged to get involved in empowerment activities that will later increase their income by utilizing their capacities and resources. At this point, boosting motivation has been included as the supporting role of social workers as motivators. Motivation is one aspect that supports the delivery of services to clients because, by the motivation given, clients can apply the motivations to empower themselves.

2) Improving awareness and providing capacity training

Increased public awareness can be achieved through primary education, while skills can be developed using the participatory method. Local knowledge owned by the community through experience can be combined with knowledge from outside. Following the statement above, in this study, SW consistently explores the clients' potential to be developed through training in the hope that the client will gain better skills, insight, and experience.

\section{3) Self-management}

Each group must be able to choose or have a leader who has the ability to organize the groups' activities later on such as holding meetings or taking notes and reporting. To select the group leader within the framework of empowerment, SW emphasized more on Rapi Ayu SME that has been well-established, synchronously with the training being conducted. In this 
study, we found that in the field SW provided motivation and advice that improve the life quality of clients who are economically versatile women.

4) Mobilization of resources

It is a method that collects resources owned by individuals in society through voluntary savings and donations, aiming at setting up social capital. At this point, the mobilization of resources has not yet materialized in the field because the community income is only enough to meet their daily needs. All we can see is SW provided capital loans to the economically versatile women in need.

5) Formation and development of network

Organizing self-help groups must be complemented by an increased capacity of its members to build and maintain networks with various social systems around them. This network is crucial in providing and developing various access to resources and empowerment opportunities for the poor. The statement follows the activities carried out by SW that continuously look for partner institutions for clients who need more excellent assistance. Based on our findings in the field, the reference theories are not entirely appropriate. There are only theoretical points that support the situation in the field as it is influenced by the clients' economic, social, and livelihood conditions. Social workers in women's socio-economic empowerment play facilitators in assisting clients in providing motivational and skill guidance. Social workers as mediators play a role in providing mediation. Social workers' role as intermediaries needs to give clients access to sources that provide support for rehabilitation service facilities [15].

\subsection{The Results of The Empowerment of Economically Versatile Women Carried Out by Social Workers in Putat Jaya Urban Village, Sawahan District, Surabaya City}

Empowerment is the efforts to increase personal strength or social assistance services that answer the lack of public access in society. his view is in line with Fahrudin, who conveyed that empowerment is the process of improving personal, interpersonal, or political power so that individuals, families, and communities can improve their condition [16]. The statement of Suharto supports the point of view that empowerment refers to the fulfillment of basic needs. The community has freedom in the sense that they are free to express their opinions and free from hunger, ignorance, and suffering, and can reach productive resources that enable them to increase their income and acquire the goods and services they need [7].

Based on these data, the empowerment of economically versatile women has enabled them to have the capacity to take action or organize activities such as training, which led to new SMEs' formation that can accommodate the training products and presented them during exhibitions. Besides, this empowerment is in the form of training and encouragement, both verbal and moral, that is consistently given to the economically versatile women. The motivation boosting made them always enthusiastic in carrying out activities. With the SW's assistance, the clients feel safer and contented because SW became a place for sharing and discussions. Additionally, the facilitators also receive facilities from the government and the private sector to continue the programs to achieve social welfare.

According to our observation, the empowerment outcomes in the field are consistent with the opinion of Shragge in Prijono and Pranarka, who argues that empowerment encourages a process of social change that enables the vulnerable marginal community to exert more significant influence in the political arena, locally and nationally [17]. In this case, the government also provides support to support the social welfare of economically vulnerable women. The government can provide an empowerment program for welfare to get more decent conditions in terms of income, housing, health, education, etc. In a family, a woman becomes a wife and plays a crucial role in running a family. When the family's needs are not met, women's role will increase to meet the needs of their families by earning additional income for the survival of all family members [18].

Thus, the results of empowerment carried out by social workers in Putat Jaya urban village, Sawahan District, Surabaya City, follow the statement of several experts that empowerment is a series of activities to strengthen the weak. By the involvement of economically versatile women in the data collection for government programs that with this program and empowerment as a social change has resulted in Rapi Ayu SME that contains the training products.

\subsection{The Impact of The Social Workers' Role on The Empowerment of Economically Versatile Women in Putat Jaya Urban Village, Sawahan District, Surabaya City}

The social worker's assistance will impact the clients who have a strong will to improve. Social workers' role is only to facilitate and serve as a bridge to achieve mutually agreed goals. These goals can be adjusted to the needs of the clients or the social worker's goals that are collaborated and conditioned to the actual situation.

The most profound or prominent impacts of social workers' role on economically versatile women empowerment in Putat Jaya urban village, Sawahan District, are including:

a) Before getting support from SW, the economy of most clients is very much dependent on other 
people. After receiving assistance from social workers, we can see the clients can work independently without others. The social workers have encouraged economically versatile women to start their businesses by taking work orders at home.

b) Clients can apply the motivations provided by SW by demonstrating better attitudes and advanced mindsets in daily life and having a high motivation to develop their talents further while also filling spare time by channeling their hobbies.

c) The impact is also seen in more comfortable access to public services, especially government programs, to meet society's needs.

As for, the efforts undertaken by social workers as facilitators, motivators, and assistants in empowerment activities show that the impacts occurred in the field are following the objectives of SW/Community Participation Program, which can improve human ability to solve problems, counter difficulties, carrying out tasks of life, and connecting clients with resources needed [19].

The data above is also inconsistent with the objectives of SW stated by Gunawan in Wulandari. In contrast, SW aims to increase the motivation, ability, and role of its members in achieving the quality of life and welfare of its members, improve the capacity of the assisted clients in identifying problems and the social and economic potential resources in an environment [13].

Similarly, this data is supported by statements of the National Association of Social Workers of the United States (NASW) in Fahrudin that are: Enhancing people's abilities to solve problems, coping, develop and connecting people with systems that provide them with resources, services, and opportunities [16]. Kabber in Laszlo et al. state that women's economic empowerment involves three interconnected dimensions: resources, agency, and achievements. Indeed, to increase a woman's economic empowerment. Women need access to resources and exercise choice, and these need to translate into achievements [20].

Women's empowerment is related to access for women in community institutions and organizations, facilitating women's socio-economic activities. Thus, women can obtain and take advantage of their rights to improving the family's economic and social life. Women's empowerment can be pursued by creating a conducive situation and strengthening the potential/power possessed by women [21].

The impact of social workers' role on empowerment activities carried out in Putat Jaya urban village, Sawahan District, Surabaya City, is in line with the references used in this study. As observed from the empowerment activities and the role of social workers composed of a series of social services conducted with an informal strategy, the community can explore their potential and needs according to their abilities and willingness so that the social empowerment formed is in favor of the community.

\section{CONCLUSION}

Based on the focus of the study, we can conclude the following: the role of social workers in the empowerment of economically versatile women are including: (a) facilitator: provide access to public facilities and social services; facilitate the provision of goods and services such as providing training; helping clients of productive age to find decent work; provide direct assistance in the form of capital or loans; (b) motivator: provide advice, motivation, and problem solutions; offer support to clients who encounter problems; identify the problem faced by the client by direct probing; (c) assistant: support clients undergoing difficulties; assist on economic empowerment; provide information; search for partner institutions, and monitor the clients.

The results of empowerment of economically versatile women carried out by Community Social Workers are actions or abilities to do activities that are useful and have never been done before, encourage the community to have the passion to continuously improving their capacity, clients feel more secure and comfortable with alternative solutions to their problem suggested by social workers.

Impacts of the social workers on the empowerment of economically versatile are include: (a) the clients are now able to work independently, starting their own business by taking orders; (b) the clients now have better attitudes and advanced mindsets in daily life; have a high motivation to develop their talents further and able to fill spare time with useful hobbies; (c) clients have easier access to public services, especially on programs implemented by the government.

Based on the conclusions as described above, there are several recommendations we can deliver, namely:

1. In delivering skills training, SW often runs out of raw materials (water hyacinth); thus, we suggest SW better anticipate this issue by preparing more raw materials in the future.

2. The empowerment activities that have been conducted should be continued to improve access to education services, mainly through non-formal education.

3. The impact of SW roles on the empowerment of economically versatile women is noticeable but not yet optimal so that the gained knowledge must be continuously developed.

\section{AUTHORS' CONTRIBUTIONS}

Rezka Arina Rahma contributed to collect the data. Sucipto contributed to the analysis and interpretation of 
data. Also, Monica Widyaswari contributed to wrote and presented the paper.

\section{ACKNOWLEDGMENTS}

The authors acknowledge social workers and clients of economically versatile women in Putat Jaya Urban Village, Surabaya, who willing to be research respondents.

\section{REFERENCES}

[1] K. Hemachandra, D. Amaratunga, and R. Haigh, "Factors affecting the women's empowerment in disaster risk governance structure in Sri Lanka," International Journal of Disaster Risk Reduction, vol. 51, p. 101779, Dec. 2020, doi: 10.1016/j.ijdrr.2020.101779.

[2] A. Fajarwati, E. L. P. Sari, and N. G. P. Soewarno, "Strategi untuk Mengatasi Permasalahan Wanita Rawan Sosial Ekonomi (WRSE)," MGI, vol. 31, no. 1, p. 22, Apr. 2017, doi: 10.22146/mgi.24227.

[3] Irma, "Identifikasi Faktor Penyebab Kerawanan Sosial Ekonomi Serta Harapan Perempuan Rawan Ekonomi (PRSE).” FIP UPI, 2014.

[4] S. Setyaningsih, C. P. Rucita, U. Hani, and I. N. Rachmania, "Women Empowerment through Creative Industry: A Case Study," Procedia Economics and Finance, vol. 4, pp. 213-222, 2012, doi: 10.1016/S2212-5671(12)00336-X.

[5] E. Duflo, "Women Empowerment and Economic Development," Journal of Economic Literature, vol. 50, no. 4, pp. 1051-1079, Dec. 2012, doi: 10.1257/jel.50.4.1051.

[6] D. Wijayanti, "Peran Pekerja Sosial dalam Menangani Masalah Remaja Putus Sekolah Terlantar." Pascasarjana UI, 2012.

[7] E. Suharto, Membangun Masyarakat Memberdayakan Rakyat, Kajian Strategis Pembangunan Kesejahteraan Rakyat Sosial dan Pekerjaan Sosial. Bandung: PT. Refika Aditama, 2014.

[8] O. M. Anwas, Pemberdayaan Masyarakat Di Era Global. Bandung: Alfabeta, 2013.

[9] S. Setyaningsih, C. P. Rucita, U. Hani, and I. N. Rachmania, "Women Empowerment through Creative Industry: A Case Study," Procedia Economics and Finance, vol. 4, pp. 213-222, 2012, doi: 10.1016/S2212-5671(12)00336-X.

[10] Robert. K. Yin, Qualitative Research from Start to Finish, First Edition. New York: The Guilford Press, 2011.
[11] J. L. Moleong, Metodologi Penelitian Kualitatif. Bandung: P. Remaja Rosdakarya, 2011.

[12] P. S. J. Singh and A. Azma, "Motivation and Leadership in Social Service Management: A Review of Theories," International Journal of Business and Social Science, vol. 8, no. 10, p. 6, 2017.

[13] F. R. Wulandari, "Peran Pekerja Sosial Masyarakat Kelompok Usaha Bersama Dalam Memberdayakan Keluarga Miskin. Skripsi tidak diterbitkan." Universitas Islam Negeri Syarif Hidayatullah Jakarta, 2011.

[14] A. Purnama, "Pemberdayaan Perempuan Rawan Sosial Ekonomi Melalui Peningkatan Kesejahteraan Keluarga," Jurnal Penelitian Kesejahteraan Sosial, vol. 17, no. 4, p. 10, 2018, doi: https://doi.org/10.31105/jpks.v17i4

[15] D. Dinardo, "Peran Pekerja Sosial Dalam Program Rehabilitasi Wanita Rawan Sosial Ekonomi Di Balai Perlindungan Dan Rehabilitasi Sosial Wanita Yogyakarta," diklus, vol. 1, no. 2, pp. 218-227, 2017, doi: 10.21831/diklus.v1i2.23872.

[16] A. Fahrudin, Pemberdayaan Partisipasi dan Penguatan Kapasitas Masyarakat. Bandung: Humaniora, 2011.

[17] O. S. Prijono and A. M. W. Pranarka, Pemberdayaan, Konsep, Kebijakan dan Implementasi. Jakarta: Centre For Strategic and International Studies (CSIS), 1996

[18] R. Khoirudin, "Wanita Rawan Sosial Ekonomi Di Kecamatan Semin, Gunungkidul," E-JEP, vol. 1, no. 2, pp. 123-133, Dec. 2019, doi: 10.29303/ejep.v1i2.14.

[19] J. Damanik, Damanik, Juda. 2008. Pekerjaan Sosial Jilid 1. Jakarta: Direktorat Pembinaan Sekolah Menengah Kejuruan, Direktorat Jenderal Manajemen Pendidikan Dasar dan Menengah, Departemen Pendidikan Nasional, 2008.

[20] S. Laszlo, K. Grantham, E. Oskay, and T. Zhang, "Grappling with the challenges of measuring women's economic empowerment in intrahousehold settings," World Development, vol. 132, p. 104959, Aug. 2020, doi: 10.1016/j.worlddev.2020.104959.

[21] K. Kushandajani, "Social and Economic Empowerment for Village Women as a Strategy of Village Development," IJPD, vol. 4, no. 1, p. 1, Feb. 2019, doi: 10.14710/ijpd.4.1.1-6. 